\title{
PENGARUH DISIPLIN KERJA, PROMOSI JABATAN, DAN IKLIM KERJATERHADAP KINERJA KARYAWAN PT. GARUDA INDONESIA PADANG
}

\author{
Waldino Putra \\ Universitas Putra Indonesia YPTK Padang \\ Waldinop25@yahoo.com
}

\begin{abstract}
ABSTRAK
Penelitian ini bertujuan untuk mengetahui dan menganalisis Pengaruh Disiplin Kerja, Promosi Jabatan, dan Iklim Kerja Terhadap Kinerja Karyawan PT. Garuda Indonesia Padang. Metode penelitian yang digunakan pada penelitian ini adalah metode deskriptif asosiatif. Sampel yang digunakan adalah sebanyak 45 responden. Metode penentuan sampel dalam penelitian ini menggunakan teknik sensus. Teknik analisis data yang digunakan dalam penelitian ini adalah regresi linear berganda, dengan bantuan program SPSS versi 20. Berdasarkan analisis statistik yang digunakan diperoleh hasil secara simultan maupun secara parsial variabel disiplin kerja, promosi jabatan, dan iklim kerja berpengaruh positif dan signifikan terhadap kinerja karyawan PT. Garuda Indonesia Padang dengan nilai kontribusi pengaruh ketiga variabel bebas tersebut di atas terhadap kinerja karyawan adalah sebesar $69,5 \%$ sedangkan sisanya 30,5\% dipengaruhi variabel lain yang tidak diteliti. Secara parsial terbukti promosi jabatan memiliki pengaruh yang paling dominan.
\end{abstract}

Kata Kunci: Disiplin Kerja, Promosi Jabatan, Iklim Kerja dan Kinerja Karyawan

\section{PENDAHULUAN}

PT Garuda Indonesia (Persero) Tbk. adalah maskapai pertama dan terbesar di Indonesia, Dengan pendekatan berorientasi "melayani", Garuda Indonesia bertujuan menjadi penyedia layanan terdepan bagi wisatawan di negara ini sekaligus menyediakan layanan pengiriman barang melalui udara. Sebagai perusahaan yang bergerak di bidang penerbangan, PT. Garuda Indonesia juga memiliki banyak pesaing dalam kegiatan usahanya. Industri penerbangan merupakan industri yang sangat kompetitif. Seiring dengan perkembangan zaman, perusahaan-perusahaan pun terus membenahi diri mempersiapkan segala konsekuensi yang mungkin terjadi.

Prawirosentono (2008:2) kinerja atau dalam bahasa inggris adalah performance yaitu hasil kerja yang dapat dicapai oleh seseorang atau sekelompok orang dalam organisasi, sesuai dengan wewenang dan tanggung jawab masing-masing dalam rangka upaya mencapai tujuan organisasi bersangkutan secara legal, tidak melanggar hukum dan sesuai dengan moral maupun etika. Perlu diketahui pula, bahwa penilaian kinerja sangat perlu dilakukan perusahaan untuk menghasilkan sumber daya manusia yang berkualitas dan berpotensi. Berikut ini adalah data penilaian kinerja pada PT. Garuda Indonesia Padang pada tahun 2013-2015: 


\section{Penilaian Kinerja KaryawanPada PT. Garuda Indonesia Padang}

Tahun 2013-2015

\begin{tabular}{|c|c|c|c|c|c|c|c|}
\hline \multirow{3}{*}{ A. Perilaku Kerja } & \multirow{3}{*}{$\begin{array}{c}\text { Bobot } \\
(\%)\end{array}$} & \multicolumn{6}{|c|}{ Tahun } \\
\hline & & \multicolumn{2}{|c|}{2013} & \multicolumn{2}{|c|}{2014} & \multicolumn{2}{|c|}{2015} \\
\hline & & $\begin{array}{l}\text { Nilai } \\
\text { Capai }\end{array}$ & $\begin{array}{c}\text { Skor } \\
(\%)\end{array}$ & $\begin{array}{l}\text { Nilai } \\
\text { Capai }\end{array}$ & $\begin{array}{c}\text { Skor } \\
(\%)\end{array}$ & $\begin{array}{l}\text { Nilai } \\
\text { Capai }\end{array}$ & $\begin{array}{c}\text { Skor } \\
(\%)\end{array}$ \\
\hline 1. Disiplin & $10 \%$ & 100 & 10 & 90 & 9 & 80,5 & 8,05 \\
\hline 2. Tanggung Jawab & $10 \%$ & 95 & 9,5 & 95 & 9,5 & 95 & 9,5 \\
\hline 3. Kerja sama & $5 \%$ & 95 & 4,75 & 90 & 4,5 & 85 & 4,25 \\
\hline 4. Kepemimpinan & $5 \%$ & 100 & 5 & 95 & 4,75 & 97 & 4,85 \\
\hline 5. $\quad$ Prakarsa & $5 \%$ & 90 & 4,5 & 95 & 4,75 & 90 & 4,5 \\
\hline 6. $\quad$ Kejujuran & $5 \%$ & 90 & 4,5 & 95 & 4,75 & 92 & 4,6 \\
\hline Jumlah & $40 \%$ & & 38,25 & & 37,25 & & 35,75 \\
\hline \multicolumn{8}{|l|}{ B. Hasil Kerja } \\
\hline 1. Kualitas kerja & $20 \%$ & 75 & 15 & 65 & 13 & 60 & 12 \\
\hline 2. Kuantitas kerja & $20 \%$ & 70 & 14 & 65 & 13 & 60 & 12 \\
\hline 3. Keterampilan kerja & $20 \%$ & 70 & 14 & 60 & 12 & 60 & 12 \\
\hline Jumlah & $60 \%$ & & 43 & & 38 & & 36 \\
\hline$\sum$ & $100 \%$ & & 81,25 & & 75,25 & & 71,75 \\
\hline
\end{tabular}

Sumber: PT. Garuda Indonesia Padang Tahun 2013-2015

Keterangan :

$\begin{array}{ll}91-100=\text { SB }(\text { Sangat Baik }) & 71-80,99=\mathrm{CB}(\text { Cukup Baik }) \\ 81-90,99=\mathrm{B}(\text { Baik }) & 61-70,99=\mathrm{KB}(\text { Kurang Baik })\end{array}$

Dari Tabel menunjukan bahwa terjadi penurunan kinerja para karyawan PT. Garuda Indonesia Padang. Dimana hasil penilaian kinerja pada tahun 2013 dalam kategori baik, kemudian pada tahun 2014 mengalami penurunan sehingga kinerja menjadi kategori cukup baik dan untuk tahun 2015 kinerja karyawan mengalami penurunan kembali, dimana kinerja karyawan menjadi kategori cukup baik. Tentunya hal ini jauh dari harapan perusahaan yang menginginkan para karyawannya memiliki kinerja yang baik. Masih ada aspek kinerja karyawan yang masih rendah tentunya menjadi bahan bagi perusahaan untuk melakukan evaluasi atas faktor-faktor yang dapat mempengaruhi capaian kinerja karyawan.

Salah satu faktor yang diduga mempengaruhi kinerja karyawan dalam penelitian ini adalah disiplin kerja. Disiplin kerja merupakan salah satu faktor yang dapat mempengaruhi kinerja pegawai. Kurangnya kedisiplinan dan tidak taatnya terhadap peraturan dan norma-norma yang berlaku maka akan berpengaruh terhadap efisiensi dan efektifitas kerja. Tingkat kehadiran merupakan salah satu indikator yang dapat mempengaruhi penilaian kinerja, baik itu keterlambatan maupun kesengajaan untuk tidak hadir bekerja (Mathis, 2011:133). Grafik dibawah ini menunjukkan data tingkat absensi di PT. Garuda Indonesia Padang. 
Jumlah Kehadiran Karyawan PT. Garuda Indonesia Padang Januari-Juni Tahun 2016 (dalam \%)

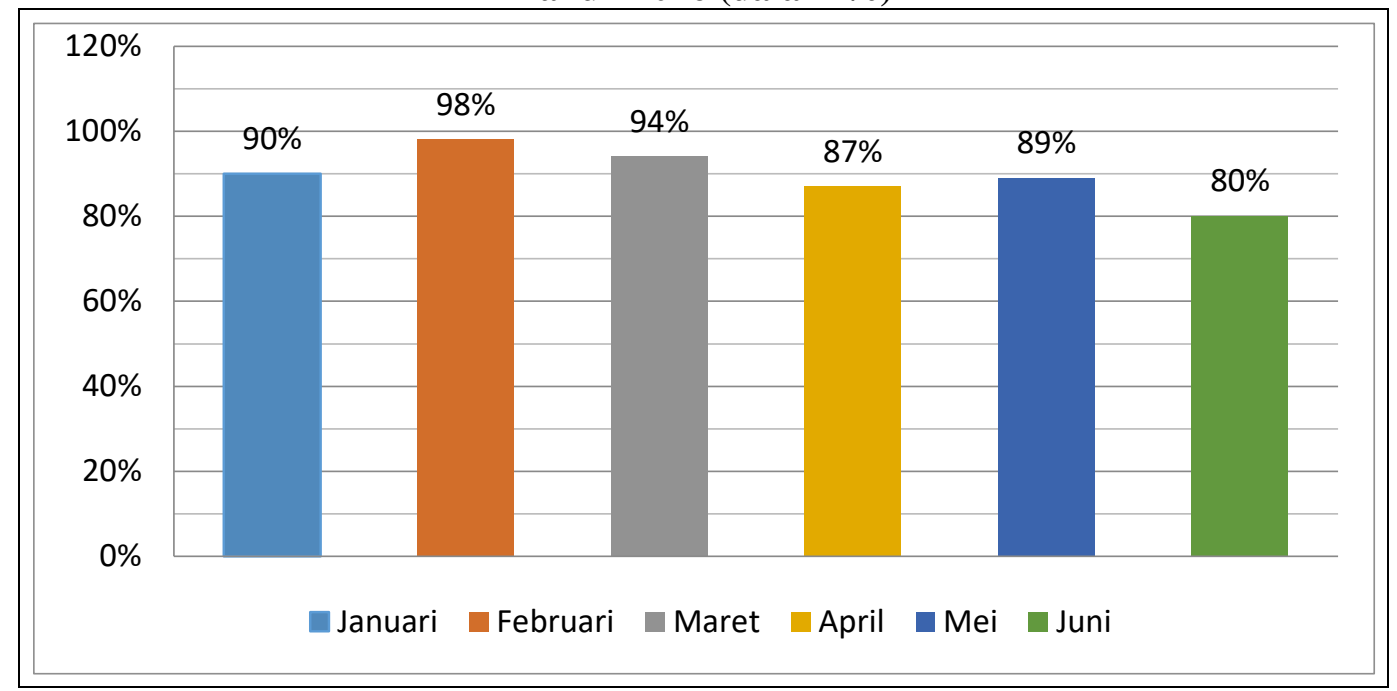

Sumber: PT. Garuda Indonesia Padang Tahun 2016

Dari data jumlah kehadiran pada grafik dapat dilihat bahwa karyawan yang masuk kerja persentasenya tidak stabil, bisa dilihat dari fluktuasi penurunan kehadiran selama 6 bulan terakhir. Berdasarkan hasil wawancara dengan beberapa karyawan PT. Garuda Indonesia Padang masih ada beberapa karyawan yang sering telat masuk kerja serta pegawai yang kurang bertanggung jawab atas hasil pekerjaannya. Ketidakhadiran karyawan menjadikan sesuatu yang sangat penting atau disebut mahal karena keridakhadiran dapat menyebabkan pekerjaan atau tugas-tugas menjadi terbengkalai.

Selain faktor disiplin kerja yang dapat mempengaruhi kinerja karyawan, promosi jabatan juga diduga mempengaruhi kinerja karyawan PT. Garuda Indonesia Padang. Menurut Rivai (2009:199) promosi terjadi apabila seorang karyawan dipindahkan dari satu pekerjaan ke pekerjaan lain yang lebih tinggi dalam pembayaran, tanggung jawab, dan atau level. Dapat disimpulkan promosi adalah perpindahan pekerjaan seseorang dari satu jabatan kejabatan yang lebih tinggi, wewenang dan tanggung jawab semakin besar, status serta pendapatan juga semakin tinggi. Bentuk promosi yang sering dilakukan PT. Garuda Indonesia Padang adalah pemberian promosi dari staff junior ke staff senior hal ini dikarenakan sebagian besar karyawan bekerja sebagai staff. Pada Tabel 1.2 dapat dilihat jumlah pegawai yang mendapat promosi pada PT. Garuda Indonesia Padang.

Jumlah Promosi Jabatan

PT. Garuda Indonesia Padang Tahun 2013-2015

\begin{tabular}{|c|c|}
\hline Tahun & Jumlah karyawan yang mendapat promosi (orang) \\
\hline 2013 & 3 \\
\hline 2014 & 4 \\
\hline 2015 & 1 \\
\hline
\end{tabular}

Sumber: PT. Garuda Indonesia Padang Tahun 2013-2015

Belum optimalnya karyawan yang mendapatkan promosi di lingkungan PT. Garuda Indonesia Padang dapat mengakibatkan penurunan kinerja karyawan. Hal disebabkan tidak tercapainya syarat-syarat seorang karyawan untuk dipromosikan. Syarat-syarat promosi tiap jabatan tidak sama karena suatu jabatan dengan jabatan lain mempunyai tugas, kewajiban dan tanggung jawab yang berbeda. Tidak meratanya sosialisasi dan keterbukaan pihak PT. Garuda Indonesia Padang dengan kriteria promosi yang akan dilakukan kepada karyawan tertentu sering menimbulkan pertanyaan di antara karyawan.

Rendahnya kinerja yang dihasilkan karyawan dalam melaksanakan tugas dan pekerjaan juga diduga ada pengaruhnya dengan iklim kerja yang kurang tepat. Hasil wawancara peneliti dengan 15 orang karyawan PT. Garuda Indonesia Padang, menyatakan bahwa karyawan merasa kondisi kantor kurang kondusif. Selain itu, kurang puasnya karyawan terhadap kebijakan yang diambil pimpinan 
terkadang direspon karyawan dengan ketidakpatuhan terhadap pelaksanaan kebijakan yang diberlakukan.

Berdasarkan fenomena di atas, rendahnya kinerja karyawan disinyalir karena rendahnya karena rendahnya disiplin kerja, tidak sesuainya promosi jabatan, dan kurang kondusif iklim kerja, maka dipandang perlu dilakukan penelitian dengan judul "Pengaruh Disiplin Kerja, Promosi Jabatan, dan Iklim Kerja Terhadap Kinerja Karyawan PT. Garuda Indonesia Padang”.

\section{LANDASAN TEORI}

\subsection{Kinerja Karyawan}

Mangkunegara (2011:67) menyatakan bahwa kinerja adalah hasil kerja secara kualitas dan kuantitas yang dicapai oleh seorang karyawan dalam melaksanakan tugasnya sesuai dengan tanggung jawab yang diberikan kepadanya.

Rivai dan Sagala (2011:548-549) mengatakan kinerja merupakan perilaku nyata yang ditampilkan setiap orang sebagai prestasi kerja yang dihasilkan oleh karyawan sesuai dengan perannya dalam perusahaan. Kinerja karyawan merupakan suatu hal yang sangat penting dalam upaya perusahaan untuk mencapai tujuannya.

Sedangkan menurut Prawirosentono (2008:2) kinerja atau dalam bahasa inggris adalah performance yaitu hasil kerja yang dapat dicapai oleh seseorang atau sekelompok orang dalam organisasi, sesuai dengan wewenang dan tanggung jawab masing-masing dalam rangka upaya mencapai tujuan organisasi bersangkutan secara legal, tidak melanggar hukum dan sesuai dengan moral maupun etika. Maka dapat disimpulkan bahwa Kinerja karyawan adalah tingkat pelaksanaan tugas yang dapat dicapai karyawan dengan menggunakan kemampuan yang ada dan batasan-batasan yang telah ditetapkan untuk mencapai tujuan organisasi.

\subsection{Disiplin Kerja}

Menurut Rivai (2009:824) kedisiplinan merupakan fungsi operatif MSDM yang terpenting, karena semakin baik disiplin karyawan pada perusahaan, maka semakin tinggi prestasi kerja yang dapat dicapai.

Menurut Hasibuan (2008:193), bahwa kedisplinan adalah kesadaran dan kesediaan seseorang mentaati semua peraturan perusahaan dan norma-norma social yang berlaku. Disiplin yang baik mencerminkan besarnya tanggung jawab seseorang terhadap tugas-tugas yang diberikan kepadanya. Hal ini akan mendorong gairah kerja, semangat kerja dan terwujudnya tujuan organisasi. Maka dapat disimpulkan bahwa Disiplin kerja karyawan merupakan sikap atau tingkah laku yang menunjukkan kesetiaan dan ketaatan seseorang atau sekelompok orang terhadap peraturan yang telah ditetapkan oleh perusahaan baik yang tertulis maupun tidak tertulis sehingga diharapkan pekerjaan yang dilakukan efektif dan efesien.

\subsection{Promosi Jabatan}

Menurut Siagian (2010:169), promosi adalah apabila seseorang dipindahkan dari satu pekerjaan ke pekerjaan lain yang tanggung jawabnya lebih besar, tingkatan hierarki jabatan lebih tinggi, dan penghasilannya pun lebih besar.

Hasibuan (2008:108), menyatakan promosi adalah perpindahan yang memperbesar authority dan responsibility karyawan ke jabatan yang lebih tinggi di dalam suatu organisasi sehingga kewajiban, hak, status, dan penghasilannya semakin besar. Maka dapat disimpulkan bahwa promosi jabatan adalah prubahan jabatan karyawan yang mempengaruhi status, tanggung jawab, dan upah yang diterima menjadi lebih tinggi dari posisi yang di jabatan sebelumnya.

\subsection{Iklim Kerja}

Menurut Litwin dan Stringer dalam Wirawan (2007: 122) mendefinisikan iklim kerja sebagai segala sesuatu yang terdapat pada lingkungan kerja yang dihayati sebagai pengaruh subjektif dari sistem formal, gaya informasi dari manajer, dan faktor lingkungan penting lainnya terhadap sikap, keyakinan, nilai, dan motivasi dari orang-orang yang bekerja dalam organisasi tertentu. 
Saptoatmojo (2008:23), bahwa lingkungan kerja dalam iklim kerja mempunyai arti penting bagi individu yang bekerja didalamnya, karena lingkungan ini akan mempengaruhi secara langsung maupun tidak langsung manusia didalamnya. Maka dapat disimpulkan bahwa iklim kerja merupakan suatu kondisi atau keadaan suasana kerja dimana seseorang dapat dengan nyaman, tenang, dan bebas dalam melakukan pekerjaan tanpa adanya rasa takut.

\subsection{Kerangka Pikir}

Berdasarkan telaah pustaka yang telah dilakukan di atas, maka model pemikiran teoritis yang dikembangkan pada penelitian ini terlihat pada gambar berikut ini :

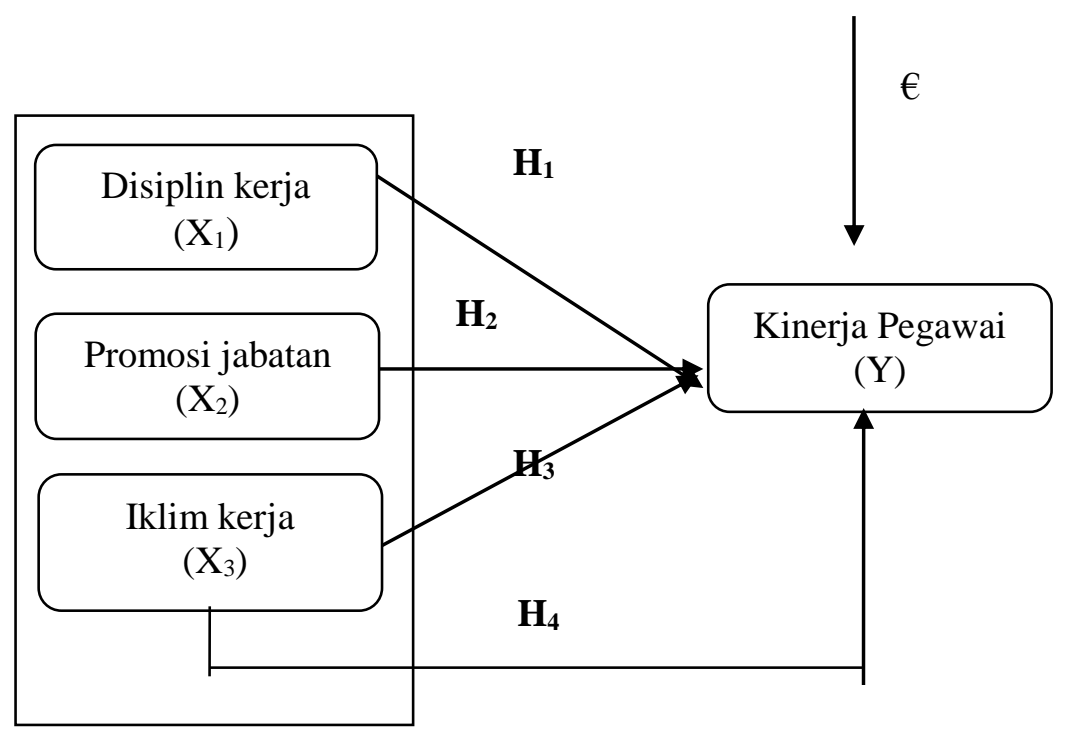

Gambar 2.1. Kerangka Berpikir

\section{METODE PENELITIAN}

Dalam penelitian ini metode yang digunakan adalah metode penelitian asosiatif, dimana dalam mengelola ini minimal harus terdapat 2 (dua) variabel yang dihubungkan. Jadi dalam metode asosiatif ini merupakan suatu penelitian yang mencari hubungan antara satu variabel dengan variabel lainnya, hal ini terkait dengan penelitian penulis mencari hubungan antara variabel dependen dan variabel independen. Dimana variabel dependen adalah kinerja karyawan dan independen adalah faktor disiplin kerja, promosi jabatan, dan iklim kerja. Selain hal di atas penulis menggunakan metode deskriptif, dimana analisa ini digunakan untuk mengetahui dan menggambarkan karakteristik responden dengan variabel.

Penelitian ini dilakukan pada PT. Garuda Indonesia Padang. Objek penelitian adalah karyawan PT. Garuda Indonesia Padang. Masalah yang akan diteliti adalah pengaruh disiplin kerja, promosi jabatan, dan iklim kerja terhadap kinerja karyawan pada PT. Garuda Indonesia Padang.

\section{HASIL PENELITIAN DAN PEMBAHASAN}

\section{a. Pengaruh Disiplin Kerja Secara Parsial Terhadap Kinerja Karyawan}

Terdapat pengaruh disiplin kerja secara parsial terhadap kinerja karyawan PT. Garuda Indonesia Padang merupakan $\mathrm{H}_{1}$ yang telah diuji dengan t-test menggunakan SPSS. Dari tabel 4.18 diperoleh nilai $t$ hitung lebih besar daripada nilai $t$ tabel $(2,132>2,109)$ dan nilai probabilitas (sig) yang dihasilkan lebih kecil dari $0,05(\alpha)(0,039<0,05)$. Berdasarkan hasil tersebut dapat disimpulkan bahwa disiplin kerja berpengaruh signifikan terhadap kinerja karyawan. Dengan demikian Ha diterima dan Ho ditolak, artinya, semakin tinggi disiplin kerja, maka semakin tinggi kinerja karyawan, sebaliknya semakin rendah disiplin kerja, maka semakin rendah disiplin kerja. 
Berdasarkan persamaan regresi diperoleh bahwa terdapat pengaruh positif dan signifikan disiplin kerja secara parsial terhadap kinerja karyawan PT. Garuda Indonesia Padang karena koefisien untuk disiplin kerja bernilai positif 0,249 . Hal ini berarti bahwa terjadi kenaikan kinerja karyawan sebesar 0,249. Untuk setiap peningkatan disiplin kerja sebesar 1 satuan dengan anggapan bahwa variabel lain tidak mengalami perubahan. Kesimpulannya adalah disiplin kerja yang tinggi akan meningkatkan kinerja karyawan.

Hasil penelitian ini konsisten dengan hasil penelitian Asmawar (2014) yang menyatakan disiplin kerja berpengaruh terhadap kinerja secara positif dan signifikan. Selanjutnya, penelitian yang dilakukan oleh Sondole (2015) menunjukkan disiplin kerja secara bersama-sama maupun parsial berpengaruh signifikan terhadap kinerja karyawan.

Berdasarkan hasil penelitian ini maka hipotesis yang diajukan oleh peneliti dapat diterima karena disiplin kerja secara parsial berpengaruh positif dan signifikan terhadap kinerja Karyawan PT. Garuda Indonesia Padang.

\section{b. Pengaruh Promosi Jabatan Secara Parsial Terhadap Kinerja Karyawan}

Terdapat pengaruh promosi jabatan secara parsial terhadap kinerja karyawan PT. Garuda Indonesia Padang merupakan $\mathrm{H}_{2}$ yang telah diuji dengan t-test menggunakan SPSS. Dari tabel 4.18 diperoleh nilai t hitung lebih besar daripada nilai t tabel $(2,319>2,109)$ dan nilai probabilitas (sig) yang dihasilkan lebih kecil dari $0,05(\alpha)(0,025<0,05)$. Berdasarkan hasil tersebut dapat disimpulkan bahwa promosi jabatan berpengaruh signifikan terhadap kinerja karyawan. Dengan demikian Ha diterima dan Ho ditolak, artinya, semakin tinggi promosi jabatan, maka semakin tinggi kinerja karyawan, sebaliknya semakin rendah promosi jabatan, maka semakin rendah kinerja karyawan.

Berdasarkan persamaan regresi diperoleh bahwa terdapat pengaruh positif dan signifikan promosi jabatan secara parsial terhadap kinerja karyawan PT. Garuda Indonesia Padang karena koefisien untuk disiplin kerja bernilai positif 0,346 . Hal ini berarti bahwa terjadi kenaikan kinerja karyawan sebesar 0,346. Untuk setiap peningkatan promosi jabatan sebesar 1 satuan dengan anggapan bahwa variabel lain tidak mengalami perubahan. Kesimpulannya adalah promosi jabatan yang tinggi akan meningkatkan kinerja karyawan.

Hasil penelitian ini konsisten dengan hasil penelitian Andriyani (2016) menunjukkan ada pengaruh positif promosi jabatan terhadap kinerja karyawan. Selanjutnya penelitian yang dilakukan oleh Munadiah (2015) yang menunjukkan bahwa promosi jabatan berpengaruh positif dan signifikan terhadap kinerja karyawan.

Berdasarkan hasil penelitian ini maka hipotesis yang diajukan oleh peneliti dapat diterima karena promosi jabatan secara parsial berpengaruh positif dan signifikan terhadap kinerja Karyawan PT. Garuda Indonesia Padang.

\section{c. Pengaruh Iklim Kerja Kerja Secara Parsial Terhadap Kinerja Pegawai}

Terdapat pengaruh iklim kerja secara parsial terhadap kinerja karyawan PT. Garuda Indonesia Padang merupakan $\mathrm{H}_{3}$ yang telah diuji dengan t-test menggunakan SPSS. Dari tabel 4.18 diperoleh nilai t hitung lebih besar daripada nilai t tabel $(3,484>2,109)$ dan nilai probabilitas (sig) yang dihasilkan lebih kecil dari $0,05(\alpha)(0,001<0,05)$. Berdasarkan hasil tersebut dapat disimpulkan bahwa iklim kerja berpengaruh signifikan terhadap kinerja karyawan. Dengan demikian Ha diterima dan Ho ditolak, artinya, semakin kondusif iklim kerja, maka semakin tinggi kinerja karyawan, sebaliknya semakin rendah tidak kondusif iklim kerja, maka semakin rendah kinerja karyawan.

Berdasarkan persamaan regresi diperoleh bahwa terdapat pengaruh positif dan signifikan iklim kerja secara parsial terhadap kinerja karyawan PT. Garuda Indonesia Padang karena koefisien untuk disiplin kerja bernilai positif 0,309 . Hal ini berarti bahwa terjadi kenaikan kinerja karyawan sebesar 0,309. Untuk setiap peningkatan iklim kerja sebesar 1 satuan dengan anggapan bahwa variabel lain tidak mengalami perubahan. Kesimpulannya adalah iklim kerja yang tinggi akan meningkatkan kinerja karyawan. 
Hasil penelitian ini konsisten dengan hasil penelitian Ulandari, dkk (2014) menunjukkan terdapat pengaruh positif iklim kerja terhadap kinerja karyawan Selanjutnya penelitian yang dilakukan oleh Usman (2011) menunjukkan bahwa Iklim kerja mempunyai pengaruh signifikan terhadap kinerja karyawan.

Berdasarkan hasil penelitian ini maka hipotesis yang diajukan oleh peneliti dapat diterima karena iklim kerja secara parsial berpengaruh positif dan signifikan terhadap kinerja Karyawan PT. Garuda Indonesia Padang.

\section{d. Pengaruh Disiplin Kerja, Promosi Jabatan, dan Iklim Kerja Secara Simultan Terhadap Kinerja Pegawai}

Hasil penelitian menemukan bahwa disiplin kerja, promosi jabatan dan iklim kerja secara simultan berpengaruh terhadap kinerja Karyawan PT. Garuda Indonesia Padang. Berdasarkan Tabel 4.19, hasil uji F diperoleh nilai $\mathrm{F}$ hitung sebesar 34,466 dengan nilai probabilitas (sig) sebesar 0,000, karena nilai $\mathrm{F}$ hitung lebih besar dari nilai $\mathrm{F}$ tabel $(34,466>2,83)$ serta nilai signifikansi kurang dari $0,05(\alpha=5 \%)(0,000<0,05)$, maka Ho ditolak dan Ha diterima, sehingga dapat disimpulkan bahwa disiplin kerja, promosi jabatan, dan iklim kerja secara simultan berpengaruh positif dan signifikan terhadap kinerja karyawan PT. Garuda Indonesia Padang.

Nilai Adjusted $R$ Square sebesar 0,695 artinya sumbangan disiplin kerja, promosi jabatan, dan iklim kerja secara simultan terhadap kinerja karyawan sebesar $69,5 \%$ sedangkan sisanya 30,5\% dipengaruhi oleh variabel lain yang tidak termasuk dalam penelitian seperti lingkungan kerja, komunikasi, kepuasan kerja dan lain sebagainya. Jika dilihat secara parsial variabel promosi jabatan merupakan variabel dengan pengaruh yang paling dominan.

\section{KESIMPULAN DAN SARAN}

\section{a. Kesimpulan}

Berdasarkan analisa data, interpretasi hasil penelitian, dan pembahasan yang telah disampaikan sebelumnya, maka dapat dikemukakan beberapa kesimpulan dari hasil penelitian ini sebagai berikut:

1. Variabel disiplin kerja secara parsial berpengaruh positif dan signifikan terhadap kinerja karyawan PT. Garuda Indonesia Padang.

2. Variabel promosi jabatan secara parsial berpengaruh positif dan signifikan terhadap kinerja karyawan PT. Garuda Indonesia Padang.

3. Variabel iklim kerja secara parsial berpengaruh positif dan signifikan terhadap kinerja karyawan PT. Garuda Indonesia Padang.

4. Variabel disiplin kerja, promosi jabatan, dan iklim kerja secara simultan berpengaruh positif dan signifikan terhadap kinerja karyawan PT. Garuda Indonesia Padang, dengan nilai Adjusted $R$ Square sebesar $69,5 \%$, sedangkan sisanya 30,5\% dipengaruhi oleh variabel lain yang tidak termasuk dalam penelitian. Jika dilihat secara parsial variabel promosi jabatan merupakan variabel dengan pengaruh yang paling dominan.

\section{b. Saran}

Berdasarkan analisis dan pembahasan hasil pengujian hipotesis, maka diajukan beberapa saran yang dapat memberikan manfaat positif bagi peneliti selanjutnya.

1. Disiplin kerja perlu tingkatkan oleh PT. Garuda Indonesia Padang karena disiplin kerja mempunyai pengaruh yang positif dan signifikan untuk meningkatkan kinerja pegawai. Seperti mematuhi jam kerja, hari kerja, ketepatan waktu masuk dan pulang kerja, menaati peraturan, mentaati prosedur kerja, serta melaksanakan tugas dan kewajibannya. Langkah-langkah yang harus diambil oleh pimpinan untuk disiplin kerja ini dengan memberikan teguran baik lisan maupun tertulis yang tegas, jelas dan tidak membeda-bedakan antara satu pegawai dengan yang lainnya agar kinerja karyawan lebih optimal.

2. Disarankan promosi jabatan lebih ditingkatkan lagi oleh PT. Garuda Indonesia Padang dengan memberikan promosi jabatan sesuai dengan prestasi kerja karyawan, sehingga karyawan lebih termotivasi dalam bekerja dan dapat mencapai tujuan perusahaan dengan optimal. Promosi 
jabatan merupakan variabel yang paling dominan mempengaruhi kinerja karyawan, karena itu perusahaan harus lebih memfokuskan pada perbaikan variabel ini.

3. Disarankan iklim kerja lebih ditingkatkan lagi oleh PT. Garuda Indonesia Padang terutama dalam hal kompensasi harus disesuaikan dengan tugas yang dijalankan oleh pegawai, memberikan kesempatan kepada pegawai untuk mengembangkan kreativitasnya, peningkatan sarana prasarana kantor sehingga memberikan kenyamanan pegawai dalam bekerja.

4. Untuk meningkatkan kinerja karyawan disarankan kepada PT. Garuda Indonesia Padang agar memperhatikan indikator-indikator kinerja karyawan yang secara rata-rata masih tingkat capaiannya hanya sebesar $76,46 \%$ berada pada kategori cukup baik.

\section{DAFTAR PUSTAKA}

[1] Andriyani, Emilla Ika. 2016. Pengaruh Gaya Kepemimpinan Terhadap Kinerja Karyawan. Universitas Sanata Dharma Yogjakarta.

[2] Asmawar. 2014. Pengaruh Kompensasi dan Pengawasan Pimpinan Terhadap Disiplin dan Dampaknya Pada Peningkatan Kinerja Pegawai Negeri Sipil Dinas Kesehatan Kabupaten Aceh Jaya. ISSN 2302-0199 Vol. 3 No.1.

[3] Bashir, Usman. 2011. Pengaruh Stress Kerja Terhadap Kinerja Karyawan. Fakultas Ekonomi Bisnis Universitas Telkom.

[4] Ghozali, Imam. 2007. Aplikasi Analisis Multivariat dengan Program SPSS. Badan Penerbit. Semarang: Universitas Diponegoro.

[5] Hasibuan, Malayu S. P. 2008. Manajemen Sumber Daya Manusia. Jakarta: PT. Bumi Aksara.

[6] L. Mathis, Robert - H. Jackson, John., 2011. Human Resource Management (edisi 10). Jakarta : Salemba Empat

[7] Mangkunegara, Anwar Prabu, A.A. 2011. Manajemen Sumber Daya Manusia. Perusahaan. Bandung : PT.Remaja Rosda Karya.

[8] Moeheriono. 2010. Pengukuran Kinerja Berbasis Kompetensi. Bogor:Penerbit. Ghalia Indonesia.

[9] Munadiah. 2015. Pengaruh Promosi Jabatan Terhadap Kinerja Pegawai Negeri Sipil di Kantor Sekretariat Daerah Kabupaten Luwu. Jurnal Adminstrasi Publik, Vol. No. 3 Desember.

[10] Prawirosentono, Suryadi. 2008. Kebijakan Kinerja Karyawan. Yogyakarta:BPFE.

[11] Priyono, Bambang Suko. 2010. Pengaruh Dimensi Karir Terhadap Kinerja Organisasi Dengan Struktur Organisasi Sebagai Moderasi. Jurnal Bisnis dan Ekonomi (JBE), Volume 17, Hal. $183-201$.

[12] Rivai, Veithzal. \& Sagala, E.J. 2009. Manajemen Sumber Daya Manusia untuk. Perusahaan. Jakarta: Rajagrafindo Persada.

[13] Rivai, Veithzal. \& Sagala, E.J. 2011. Manajemen Sumber Daya Manusia untuk. Perusahaan dari Teori ke Praktik. Jakarta: Rajagrafindo Persada.

[14] Saptoatmojo. 2008. Pengantar Personalia Dalam Organisasi Teknik. Bandung: Tarsito.

[15] Siagian, Sondang P. 2010. Manajemen Sumber Daya Manusia, Cetakan keenam belas. Jakarta: PT.Bumi Aksara.

[16] Simamora, Henry. 2006. Manajemen Sumber Daya Manusia, Edisi 2. Yogyakarta: STIE YKPN.

[17] Simanjuntak, Payaman, J. 2011. Manajemen Dan Evaluasi Kinerja, Jakarta: Fakultas. Ekonomi UI.

[18] Sugiyono. 2011. Metode Penelitian Bisnis. Bandung: Alfabeta.

[19] Sulistiyani, Ambar T dan Rosidah. 2009. Manajemen Sumber Daya Manusia. Yogyakarta: Graha Ilmu.

[20] Ulandari, Luh D., Zukhri, Anjuman., Suwena, Kadek R. 2014. Pengaruh Iklim Kerja Terhadap Karyawan Pada PT. Diva Elektronika Singaraja. Universitas Pendidikan Ganesha.

[21] Wirawan. (2009). Evaluasi Kinerja Sumber Daya Manusia Teori Aplikasi dan Penelitian. Jakarta. Penerbit: Salemba Empat. 